\title{
A COUNTERCYCLICAL FRAMEWORK FOR A DEVELOPMENT-FRIENDLY INTERNATIONAL FINANCIAL ARCHITECTURE
}

\author{
José Antonio Ocampo and Stephany Griffith-Jones*
}

The last three decades made developing countries, and particularly those more integrated into world financial markets, swing at the rhythm of highly procyclical external financing. Financial volatility has a direct effect on the balance of payments and domestic financial market, and through them on domestic economic activity and other macroeconomic variables. In the face of strong swings of private capital markets, developing countries lost "policy space" to adopt autonomous countercyclical macroeconomic policies, and faced difficult challenges creating deep financial markets. A vicious circle involving procyclical financing, incomplete financial markets and institutions, and constraints to macroeconomic policy emerged: imperfect financial markets have been a source of volatility, but deep financial markets, improved financial governance structures and countercyclical macroeconomic policies have been difficult to develop in a highly volatile financial environment (Fanelli, 2006). The unfortunate outcome of this dynamics is that "twin" external and domestic financial crises became far more frequent since the breakdown of Bretton Woods exchange rate arrangements (IMF, 1998; Bordo et al., 2001).

This paper thus argues forcefully that the major task of a development-friendly international financial architecture is to mitigate the procyclical effects of financial markets and open "policy space" for countercyclical macroeconomic policies in the developing world. We look first at features and costs of capital account volatility and the underlying international asymmetries, then at different ways to reduce such volatility and open space for countercyclical macroeconomic policies.

\footnotetext{
* Under-Secretary-General of the United Nations for Economic and Social Affairs and Professorial Fellow of Institute of Development Studies of the University of Sussex, respectively. This paper was prepared for the CEDES/IDRC Project on "International Financial Architecture, Macro Volatility and Institutions: The Developing Country Experience". We are grateful to José María Fanelli and Jan Kregel for comments.
} 


\section{Capital account volatility in the developing world}

Trade and terms of trade fluctuations play a major role in the determination of business cycles in developing countries, particularly in commodity-dependent economies. Domestic macroeconomic policies and political factors also play a role in determining business cycles. Since the 1970s, however, business cycles in developing countries have been characterized by the leading role played by capital account fluctuations. This has been particularly true for economies more integrated into world financial markets, the "emerging economies".

Boom-bust cycles reflect investor herding and associated contagion -of both optimism and pessimism. Volatility is associated with significant changes in risk evaluation, which involve the alternation of periods of "appetite for risk" (more precisely, underestimation of risks) with periods of a "flight to quality" (risk aversion). Marketsensitive risk management practices as well as other features of financial markets (e.g. evaluation of managers against competitors) increase herding (Persaud, 2000). Furthermore, due to information asymmetries, different assets tend to be pooled together in risk categories that are viewed by market agents as being strongly correlated. This practice turns such correlations into self-fulfilling prophecies.

Boom-bust cycles have given a renewed relevance to endogenous unstable dynamics of financial markets analyzed by Minsky (1982), who emphasizes how financial booms generate excessive risk taking by market agents, which eventually leads economies into crises. From a different theoretical perspective, a similar explanation has been recently suggested by White (2006), who underscores how "search for yield" characteristic of low interest rate environments generates incentives for credit creation, carry trade and leverage that easily build up asset bubbles. "The main risks to the financial sector could stem from financial excesses linked to a generalized complacency towards risk reinforced by a benign short-term outlook" (BIS, 2005, p. 120). A low inflation environment may actually encourage such behavior, as monetary policy tends to be accommodative and may even (according to influential views, such as those of Alan Greenspan) be powerless in the face of asset price bubbles, although it can later mitigate

effects of asset price busting. This was evident in Japan in the 1990s as well as the US in the 2000 s. 
In developing countries, fluctuations in capital markets are reflected in the procyclical pattern of spreads, variations in the availability of financing (absence or presence of credit rationing) and in maturities. This involves short-term volatility, such as very intense upward movement of spreads and the short periods of interruption (rationing) of financing observed during the Mexican, Asian and the Russian crises. More importantly, they also involve medium-term cycles, as the experience of the past three decades indicates (see Figure 1 in relation to spreads since 1994). During this period, two full medium-term cycles were experienced: a boom of external financing in the 1970s, followed by a major debt crisis in the 1980s; a new boom in the 1990s, followed by a sharp reduction in net flows after the Asian and Russian crises of 1997-98. Since 2002-03 a new such cycle has been in place, which already underwent a phase of turbulence in May/June 2006.

FIGURE 1

\section{EMERGING MARKETS SPREADS}

Spreads on JP Morgan EMBI Global and US High-Yield Bonds October 1994 to June 2006

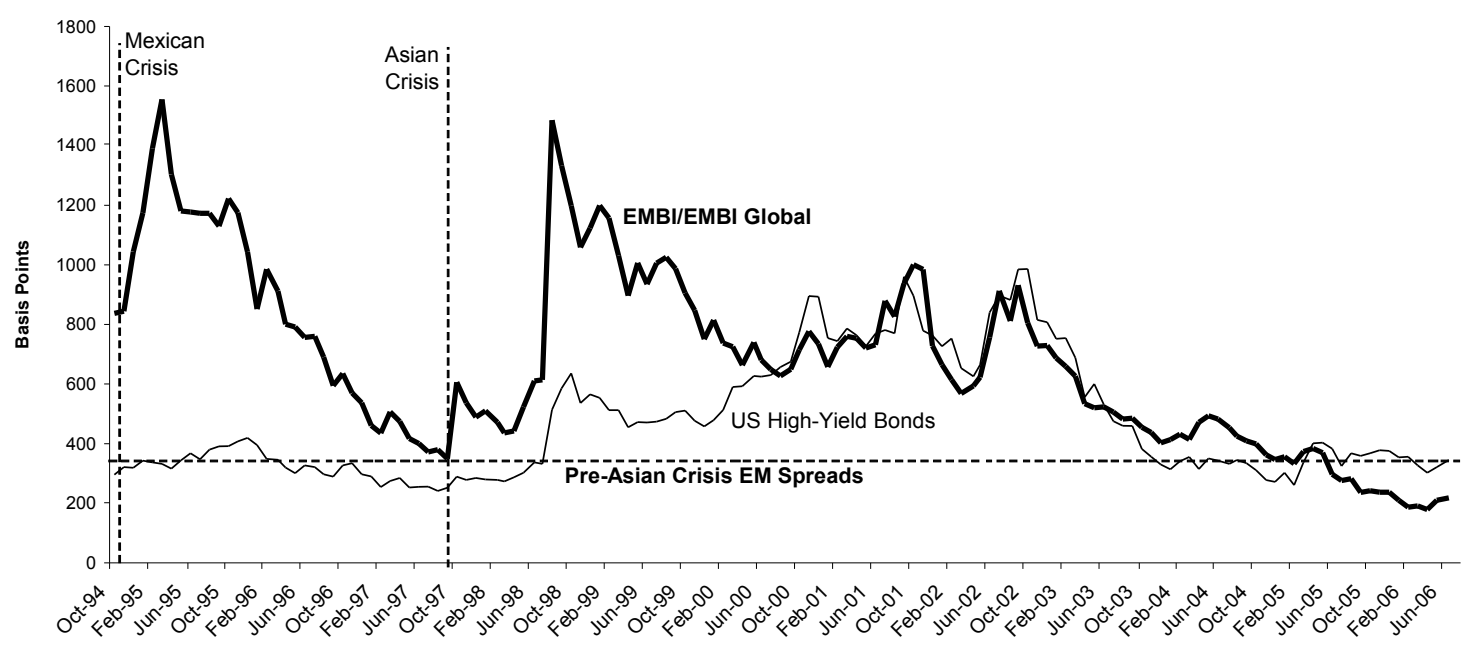

Source: ECLAC, on the basis of data from Merrill Lynch's U.S. High-Yield Master II Index (H0A0), JP Morgan Chase's EMBI and EMBI Global.

Interestingly, as Figure 1 also indicates, fluctuations in risk premia for emerging markets tend to correlate with spreads of US high-yield bonds. Thus, the procyclicality of financial markets affects all types of assets considered risky by market agents. The 
correlation is imperfect, though, reflecting specific factors that determine different asset classes.

Different types of capital flows show different volatility patterns. The higher volatility of short-term capital indicates reliance on such financing is highly risky (Rodrik and Velasco, 2000), whereas the smaller volatility of FDI vis-à-vis all forms of financial flows is considered a source of strength. However, "financial engineering" may be making different flows increasingly similar. Particularly, the use of risk management techniques by multinationals, via derivatives, may make FDI in critical moments as volatile as traditional financial flows.

Volatility in financial markets is partly transmitted to developing countries through public-sector accounts, especially through effects of the availability of financing on government spending, and of interest rates on public sector debt service payments. In commodity-dependent developing countries, links between availability of financing and commodity prices reinforce the effects on public sector accounts. However, the most important effects of capital-account fluctuations are on private spending and balance sheets. Capital-account cycles, their domestic financial multipliers and their reflection in asset prices have thus become the major determinant of growth volatility in the developing world, whereas price and wage rigidities emphasized in the "neo-classical synthesis" have played a rather secondary or even insignificant role (Easterly et al., 2001).

During booms, developing countries viewed by markets as "success" stories are almost inevitably drawn into the capital account boom, inducing private-sector deficits and risky balance sheets (Ffrench-Davis, 2001; Marfán, 2005). However, even countries with weak "fundamentals" may be drawn into the boom (see, for example, Calvo et al. 1993) and all countries, again with some independence from their "fundamentals", will be drawn into "sudden stops" of external financing (Calvo and Talvi, 2004). What market judges as "success stories" during booms and "pariahs" during crises may also be subject to cyclical variations. Notice, for example, the transformation of Argentina from "success story" to pariah of financial markets and the opposite evolution of Russia since 1998. This means that the concept of "macroeconomic fundamentals" and, particularly, the market evaluation of such "fundamentals" must be taken with a grain of salt. However, 
some objective macroeconomic factors do help to determine vulnerability to crises, particularly large current account imbalances and weak financial sectors.

Conditions are particularly difficult in developing countries during crises, because rising risk premiums and reduced availability of external financing may eliminate the room for countercyclical monetary and fiscal policies, and may rather force them to adopt procyclical policies -i.e., high interest rates and tight fiscal policies. Thus, while industrial countries can smooth procyclical effects of credit and asset prices through countercyclical macroeconomic policies, developing countries may be forced to adopt procyclical macroeconomic policies that reinforce the procyclical movements of financial markets. Indeed, the "credibility" of authorities to financial market agents during crises will be judged according to their capacity to adopt austerity policies. Interaction between increases in country risk premia and reduced availability of financing during crises can be particularly destabilizing in economies with high debt ratios (Frenkel, 2005).

There is also widespread evidence that ample private sector financing encourages procyclical macroeconomic policies during booms. Austerity policies during crises may generate a political economy bias toward expansion when financing becomes again available. In turn, ample private sector financing encourages procyclical responses from markets and macroeconomic authorities. Thus, unstable external financing distorts incentives that both private agents and authorities face throughout the business cycle, inducing a procyclical behavior of economic agents and macroeconomic policies (Kamisky et al., 2004; United Nations, 2006). In the words of Stiglitz (2003), increased exposure to financial market risks replaced Keynesian automatic stabilizers with automatic $d e$-stabilizers. Contrary to the view that, with liberalization, financial markets would play a disciplining role, dependence on financial swings encouraged adoption of procyclical monetary and fiscal policies that increased both real macroeconomic instability and the alternation of financial euphoria and crises.

Crises are deleterious for financial development and institution building, as they destroy the "rules of the game" for financial transactions and it takes time to build new rules. They also generate endogenous responses in financial structures that contribute to volatility: shallow markets for long-term instruments, missing markets for risk transactions, market segmentation, liquidity constraints for many market agents and, in 
some cases, dollar/euroization (Fanelli, 2006). One of the most important effects are the endemic maturity and currency mismatches that characterize balance sheets of economic agents in developing countries. Maturity and currency risks are accumulated during periods of financial euphoria; thus, the sharp reduction in liquidity, increased domestic interest rates and exchange rate depreciations during crises have strong balance sheet effects.

Although procyclicality is inherent in financial markets, domestic financial and capital account liberalization in the developing world have accentuated its effects. A lag in developing adequate prudential regulation and supervision frameworks increases the risks of financial liberalization. The development of appropriate financial governance structures is itself made difficult in volatile financial environments, and they only help to mitigate (i.e., they do not eliminate) the increased volatility that financial liberalization generates.

The costs of such financial volatility in the developing world in terms of economic growth are high. There is now overwhelming evidence that procyclical financial markets and macroeconomic policies have increased growth volatility and have not encouraged growth in the developing world (Prasad et al., 2003). Whatever the efficiency gains from financial market integration, they are swamped by the negative effects of growth volatility.

Eichengreen (2004) estimated that over the past 25 years, income of developing countries had been $25 \%$ lower due to currency and banking crises. Others have estimated even higher average annual costs of crises. Indonesia experienced larger falls in output and incomes during the Asian crisis than the United States during the Great Depression. In the presence of increasing returns, such strong recessions generate cumulative effects (Easterly, 2001, chapter 10). In the most adverse cases, it will lead to a displacement in the long-term growth trajectory (e.g., most Latin American countries in the 1980s, or Indonesia since the Asian crisis).

Each medium term financial cycle may have specific features. The current one has been characterized by an unprecedented accumulation of international reserves and reduced debt ratios -"self-insurance" against the financial instability experienced during 
previous crises. Such "self-insurance", together with booming exports and the rapid development of local currency bond markets (see below), may have changed conditions surrounding developing country financing in recent years.

However, new risks have emerged or become more prominent. First, increased dependence of developing countries on export-led strategies and on high commodity prices have made them more vulnerable to trade cycles. The interaction between trade and capital account fluctuations has been a traditional source of vulnerability, but may be assuming new dimensions given higher openness of most developing countries.

Second, new sources of potential procyclicality have emerged, particularly related to the explosive growth of derivatives worldwide. In developing economies, derivative contracts are being used both as instruments to hedge risk and for international hedge funds and investment banks to speculate, for example via the "carry trade". Large parts of these derivative markets are not regulated (as they operate in the OTC market and offshore). Nor have existing regulations fully incorporated the risks that derivatives pose in situations of stress, when they can add to systemic risk.

Third, uncertainties associated with the risk of a disorderly unraveling of global imbalances may drastically change the prospect for developing economies. A major paradox is that measures of "self-insurance" of developing countries (large current account surpluses, increased international reserves and reduced indebtedness) are also part of global imbalances. The new sources of strength of developing countries, when viewed on a country-by-country basis, turn out to be one of the elements of vulnerability for developing countries as a whole. A global co-operative approach to provision of "collective insurance" and management of global imbalances would thus be a more desirable solution (Ocampo, Kregel and Griffith-Jones, 2006, chapter IV).

\section{Implications of financial volatility for international cooperation}

\section{a. The underlying financial and macroeconomic asymmetries}

The dynamics of boom-bust cycles is deeply rooted in the operation of financial markets, and in basic asymmetries that characterize the world economy (Ocampo and Martin, 2003). In the financial area, such asymmetries are reflected in: (i) incapacity of 
most developing countries to issue liabilities in international markets in their own currencies, a phenomenon referred to as "original sin" (Eichengreen et al., 2003; Hausman and Panizza, 2003), partly mitigated by recent growth of local currency debt markets; (ii) differences in the degree of domestic financial and capital market development, which lead to an under-supply of long-term financial instruments; and (iii) the small size of developing countries' domestic financial markets vis-à-vis the magnitude of speculative pressures they may face. This implies that domestic financial markets in the developing world are significantly more "incomplete" than in the industrial world and thus that some financial intermediation must be conducted through international markets. Developing countries are plagued with a myriad of financial market imperfections, particularly by variable mixes of currency and maturity mismatches. Financial asymmetries generate, in turn, important macroeconomic asymmetries, particularly in the capacity of developing countries to undertake countercyclical macroeconomic policies.

The risks associated with financial instability can be partly corrected by domestic policy actions, involving variable mixes of foreign exchange reserve accumulation during booms, countercyclical fiscal policies, strengthened prudential regulation and supervision, and variable mixes of exchange rate intervention, management of the capital account (including through incentives to reduce debt or improve its term structure during booms) and use of the margins for countercyclical monetary policy that those policies generate (Ocampo, 2005).

However, such actions are not costless. Thus, the accumulation of international reserves to cover risks associated with short-term capital is usually expensive. The risks faced by the domestic financial sector can be counterbalanced by stricter prudential regulations but this raises the cost of financial intermediation and may restrict the development of new financial services. Furthermore, many regulatory actions that emerging economies can adopt to manage risks merely shift rather than correct the underlying risks.

The public sector (including the central bank) can also act as the "insurer of last resort" of private sector risks, through the issue of foreign currency denominated bonds that the private sector can use to cover its currency mismatches. Although this may help 
the private sector to absorb shocks, it implies additional public sector liabilities and, possibly, a larger tax burden to service them. The Brazilian experience provides the best example of the potential costs of such risk absorption strategy (Souza, Silveira and Carvalho, 2006).

There is a profound sense in which financial and macroeconomic asymmetries that affect developing countries are inescapable. The search for shortcuts and "silver bullets" (hard pegs or the adoption of international currencies) does not eliminate the difficult tradeoffs that such asymmetries generate.

\section{b. Implications for the design of the international financial architecture}

The wave of crises in the developing world has underscored the need for a broad framework for macroeconomic stability. In the recent debate, this has been reflected in the focus on sustainability, including external, fiscal and financial sector sustainability (IMF, 2004). But given the procyclical bias of financial markets and the strong incentives to adopt procyclical macroeconomic policies, an equally important emphasis should be given to the countercyclical dimensions of macroeconomic and financial policies.

The countercyclical dimensions have received much less attention in recent debates. This is reflected in the absence of this concept in the new IMF Medium-Term Framework (IMF, 2005a). This contrasts with the importance this concept played in past macroeconomic debates and the explicitly countercyclical focus of macroeconomic policies in some industrial economies, particularly the United States. It is also in contrast with the call by the major grouping in developing countries in financial issues, the Group of 24 (2005), to include explicit countercyclical objectives in the IMF's support to developing countries. In this area, there is an increasing consensus on the need to use expansionary periods to strengthen fiscal positions, and a more limited recognition of the need to avoid explicitly procyclical fiscal policies during crises (such as targeting the current deficit in a context in which tax revenues are declining). However, this represents only a very limited recognition of the need to fully mainstream countercyclical concerns in designing macroeconomic frameworks. 
It has also become increasingly recognized that liberalized capital accounts and financial markets generate excessively risky private sector balance sheets, and that excessive reliance on short-term external financing enhances the risk of currency crises. Preventive (prudential) macroeconomic and financial policies, which aim at avoiding the accumulation of unsustainable public and private sector debts and balance sheets during periods of financial euphoria, have thus become part of the standard recipe. However, even well-established countercyclical prudential practices, such as the Spanish system of forward-looking provisions, have received limited attention, and the need to reduce procyclicality was not given adequate attention in the revision of Basle standards. Rather, Basle II may increase procyclicality of both international and domestic bank lending.

Managing countercyclical policies for developing countries in the current globalized financial world is, of course, no easy task, as financial markets generate strong incentives to adopt procyclical policies and reduce the room of maneuver to undertake countercyclical macroeconomic policies. It is thus essential that international cooperation in the macroeconomic policy area be designed to overcome such incentives and constraints.

This means that the first role of international financial institutions, from the point of view of developing countries, is to mitigate the procyclical effects of financial markets and open "policy space" for countercyclical macroeconomic policies. This can be achieved by: (i) smoothing out boom-bust cycles at the source through regulation; (ii) helping partially cover or diversify the risks (especially of a cyclical nature) developing countries face in international capital markets; and (iii) increasing incentives and degrees of freedom that developing countries have to adopt countercyclical policies.

A number of measures can be suggested. They include: (i) explicit introduction of countercyclical criteria in the design of prudential regulatory and supervisory frameworks, in capital source and developing countries; (ii) designing market mechanisms that better distribute the risk faced by developing countries throughout the business cycle (GDP indexed and local currency bonds); (iii) instruments that encourage more stable private flows, such as countercyclical guarantees; and (iv) countercyclical official liquidity to deal with external shocks. Since the design of a development-friendly 
international financial architecture should include not only global but also a complete network of regional institutions, we examine cooperation among developing countries.

\section{Countercyclical prudential regulation and supervision}

The origins of problems that erupt during financial crises are associated with both excessive risk-taking during booms and the inevitable mix of maturity and currency mismatches that characterize balance sheets in developing countries. Inadequate risk analysis by financial agents and weak prudential regulation of domestic financial systems exacerbate this. However, even well-regulated systems in industrial countries are subject to periodic episodes when risks are underestimated. In Argentina a system of prudential regulations considered to be one of the best in the developing world - and with largescale presence of multinational banks - failed to avert effects of major macroeconomic shocks on the domestic financial system.

One of the major problems seems to be the focus of prudential regulation on microeconomic risks, and the tendency to underestimate risks that have a clear macroeconomic origin. ${ }^{1}$ Whereas microeconomic risk management can reduce risks that depend on individual characteristics of each borrower through diversification, they cannot reduce systematic risks, associated, for example, with business cycles. The basic problem in this regard is the inability of individual financial intermediaries to internalize collective risks assumed during boom periods.

Moreover, traditional regulatory tools, including both Basle I and Basle II standards, have a procyclical bias. The basic problem is the highly procyclical nature of a system in which loan-loss provisions are tied to loan delinquency or to short-term expectations of future loan losses. Such system may be ineffective in hampering excessive risk-taking during booms, when expectations of loan losses are low, thus effectively underestimating risks and the counterpart provisions for loan-losses. The sharp increase in loan delinquency during crises reduces financial institutions' capital and, hence, their lending capacity, potentially triggering a "credit squeeze"; this would reinforce the downswing in economic activity and asset prices and, thus, the quality of

\footnotetext{
${ }^{1}$ For recent analyses of these issues and policy options for managing them, see BIS (2001, Ch. VII;) and Ocampo (2003).
} 
the portfolios of financial intermediaries. Since credit ratings are also procyclical, basing risk on such ratings is also procyclical.

Given the central role all these processes play in business cycles of developing countries, and the important influence of banking regulation on credit availability in the modern economy, the crucial issue is to introduce a countercyclical element into prudential regulation and supervision. The major innovation is the Spanish system of forward-looking provisions, introduced in 2000 and modified in 2005, and later adopted by Portugal. According to this system, provisions are made when loans are disbursed based on the expected losses ("latent risks"), estimated on the basis of a full business cycle (Fernández de Lis, et al., 2001). This system implies that provisioning follows the criteria traditionally used by the insurance industry, where provisions are made when the insurance policy is issued.

Under this system, provisions build up during economic expansions and are drawn upon during downturns. They are accumulated in a fund, which is used to cover loan losses. Although the accumulation and drawing down of the fund has a countercyclical dynamic, this only reflects the cyclical pattern of bank lending. Thus, the system is, strictly speaking, "cycle-neutral". It can be complemented by strictly countercyclical prudential provisions, which can be decreed by the regulatory authority for the financial system as a whole or for some financial agents on the basis of the excessive growth of credit (relative to some benchmark), the bias in lending to sectors characterized by systematic risks and the growth of foreign-currency denominated loans to non-tradable sectors.

The explicit analysis of the countercyclical elements of prudential regulation and supervision should thus become a central concern of the Basle Committee. The benefits to developing countries would accrue through both a less procyclical supply of credit and more resilient domestic financial systems.

Ensuring a more precise measurement of risk in bank portfolios should also be the subject of attention in drafting international accounting standards. Indeed, existing standards give no room for concepts such as the "latent risks" in bank portfolios, leading to both an overestimation of their "fair value" during periods of euphoria and an 
underestimation during phases of excessive pessimism. The tax system should also accept such transparent provisions as fiscal costs.

In developing countries these provisions should be supplemented by more specific regulations aimed at controlling currency and maturity mismatches (including those associated with derivative operations), and at avoiding the overvaluation of collateral generated by asset price bubbles. The strict prohibition of currency mismatches in the portfolios of financial intermediaries is the best rule, but authorities should also closely monitor currency risk of non-financial firms operating in non-tradable sectors, which may become credit risks for banks. Regulations can be used to establish higher provisions and/or risk weighting for these operations, or a strict prohibition on lending in foreign currencies to non-financial firms without revenues in those currencies.

Moreover, many regulatory practices aimed at correcting risky practices shift underlying risks to non-financial agents. Thus, for example, lower risk ratings for shortterm credit and strong liquidity requirements reduce direct banking risks, but also reinforce the short-term bias in lending. Maturity mismatches are thus displaced to nonfinancial agents and may result in reduced fixed capital investment. Also, prudential regulations forbidding banks from holding currency mismatches in their portfolios may encourage non-financial agents to borrow directly from abroad. Reduced direct vulnerability of the domestic financial sector will have, as a corollary, the currency and, possibly, maturity mismatches of non-financial agents. This is why capital account regulations aimed at avoiding inadequate maturity structure of borrowing in external markets by all domestic agents, and at avoiding currency mismatches in the portfolios of those agents operating in non-tradable sectors, may be the best available option (Ocampo, 2003). Also, as long as there is no international lender of last resort, international rules should continue to provide room for the use of capital account regulation by developing countries.

The evaluation of the vulnerability of domestic financial system and the development of regulatory and supervisory frameworks have become essential elements of financial sector assessments undertaken by the IMF and the World Bank. It is essential that the macroeconomic and, particularly, the countercyclical dimensions of prudential 
regulation and supervision be equally and routinely incorporated in such assessments and advice.

In addition, Basle II has a number of problems that require attention: it is complex where it should be simple; it is implicitly procyclical when it should be explicitly countercyclical; and although it is supposed to more accurately align regulatory capital to the risks that banks face, in the case of lending to developing countries it ignores the proved benefits of diversification. In particular, by failing to take account of the benefits of international diversification of portfolios, capital requirements for loans to developing countries will be significantly higher than is justified on the basis of the actual risks attached to such lending. There are thus fears that Basel II creates the risk of a sharp reduction in bank lending to developing countries, particularly during crises (thus enhancing the procyclicality of such lending), and of an increase in the cost of a significant part of the remaining lending, particularly for low-rated borrowing countries.

One clear way in which Basle II could be improved to reduce these problems would be to introduce the benefits of diversification into the internal-ratings based approach. One of the major benefits of investing in developing and emerging economies is their relatively low correlation with mature markets. This has been tested empirically using a wide variety of financial, market and macro variables. Different simulations that compared estimated losses of portfolios that were diversified across both developed and developing countries with the losses of portfolios in developed countries only, indicate that the former were from 19 to 23 per cent lower (Griffith-Jones, Segoviano and Spratt, 2004). If risks are measured precisely, this should be reflected in lower capital requirements.

An additional positive effect of taking account of the benefits of diversification is that this makes capital requirements far less procyclical than otherwise. Indeed, if the benefits of diversification are incorporated, simulations show that the variance over time of capital requirements will be significantly smaller than if they are not.

\section{Market instruments}

a. $\quad$ GDP-linked bonds 
GDP-linked bonds could be particularly beneficial to smooth debt service payments by linking part of the annual debt servicing of the bond to the growth of the debtor country's GDP growth (Griffith-Jones and Sharma, 2006). The interest coupon would be totally or partially tied to the issuing country's rate of growth. Given the requirement for many institutional investors to hold assets that pay a positive interest rate, a floor can be determined beyond which the coupon rate cannot fall.

GDP-indexed bonds could be beneficial for all countries, but especially for developing ones. They would provide two major benefits for them. First, they stabilize government spending and limit the procyclicality of fiscal pressures by requiring smaller interest payments at times of slower growth -thus providing space for higher spending or lower taxes during crises. They also curb excessively expansionary policy in times of rapid growth. The issuance of such bonds would make it easier for governments to follow countercyclical fiscal policies. Second, by allowing debt service ratios to fall in times of slow or negative growth, they reduce the likelihood of defaults and debt crisis.

Simulations indicate that gains for emerging-economy borrowers can be substantial. Research by Borensztein and Mauro (2004) shows that, if half of Mexico's government debt consisted of GDP-indexed bonds, it would have saved about $1.6 \%$ of GDP in interest payments during the Tequila crisis of 1995.

To help create a market for these instruments, it may be better if they were issued first by countries with greater credibility. Two such groups of countries can be identified. The first are developed countries. The second are developing countries, like Mexico or Chile, that are attractive to markets. The precedent of introducing collective action clauses into bonds, done first by developed countries and later followed by developing ones, shows that demonstration effects can be very effective for introducing financial innovations. Positive precedents -e.g., by investors with Argentine warrants that provide an upside of debt servicing if growth is above a fixed level- also create a propitious climate for them.

GDP-indexed bonds may also provide benefits for issuer industrialized countries, especially in Europe. They may be particularly attractive for EMU countries, given that the "Stability and Growth Pact" tends to render their fiscal policies procyclical if their 
structural fiscal position is not too distant from the maximum allowed deficit (3\% of GDP). They are also particularly relevant for European countries where pensions are indexed against GDP growth, such as Italy.

Investors are likely to receive two main benefits from the introduction of GDPlinked bonds. First, they would provide an opportunity to take a position on countries' future growth prospects. Though this is possible to some degree through stock markets, these are often not representative of the economy as a whole. Since growth rates across emerging markets tend to be fairly uncorrelated, a portfolio including GDP-indexed bonds for several of these economies would have the benefits of diversification, thus increasing the return/risk ratio. Second, investors would benefit from a lower frequency of defaults and financial crises, which often results in costly litigations/renegotiation and sometimes in outright losses.

On a broader level, GDP-indexed bonds can be viewed as desirable vehicles for international risk-sharing, as a way of avoiding the disruptions from formal defaults and as a mechanism to help smooth growth. They have the characteristic of a public good as they generate systemic benefits above those going to individual investors and issuing countries.

These externalities provide a justification for some public action to help create such a market. Thus, the World Bank and regional development banks could play the role of "market makers" for GDP-linked bonds (Ocampo, Kregel and Griffith-Jones, 2006, Chapter II). These institutions could begin by developing a portfolio of loans, the repayments of which could be indexed to the growth rate of the debtor country. Once they have a portfolio of such loans to different developing countries, they could securitize them and sell them in the international capital markets. Such a portfolio could be particularly attractive for private investors as it would offer them the opportunity of taking a position on the growth prospects of a number of emerging economies simultaneously. As correlations among growth rates of developing countries tend to be lower at the global level, the World Bank may be best placed to do such securitization. One disadvantage of GDP-linked bonds is that developing countries' ability to pay is not only associated with GDP growth but also with the ability to generate a sufficient supply of foreign exchange, and thus with the evolution of the real exchange rate. To the extent 
that fluctuations of this variable are procyclical, real exchange rate volatility will compound GDP fluctuations. These instruments could be eventually indexed to GDP measured in the currency of issuance of the bonds, but this may reduce their attractiveness.

But perhaps the main concern for developing a GDP-linked bond market is uncertainty about their future liquidity. This has been a problem for issuing other new instruments such as inflation-indexed bonds. However, such problems have been overcome once such paper was issued on a significant scale.

\section{b. $\quad$ Local Currency Bonds}

Another alternative for better managing the risks faced by developing countries throughout the business cycle consists of the introduction of local currency-denominated bonds. These bonds offer a cure against the currency mismatches that characterize the debt structure of developing countries. At the domestic level, the development of domestic capital markets, especially bond markets, also creates a more stable source of local funding for both the public and private sectors, mitigating difficulties created by sudden stops in cross-border capital flows.

The recognition of their virtues has been reflected in a boom of domestic bond markets in developing countries since the Asian crisis (see Figure 2). The financial infrastructure required to provide adequate liquidity involves adequate regulation, wellstructured stock and bond markets - with bonds usually providing a larger market in most countries - and investment banks which play the role of "market makers" to help provide liquidity. There is also growing attention to issuing local currency denominated bonds in international markets, but these instruments still represent a small though growing share of the market. As the experience of those countries that have been more successful in issuing these bonds indicates (e.g., South Africa), they are largely used to cover the currency risks of long-term investors.

Domestic markets for these instruments also tend to be less liquid than similar markets in industrial countries, and the reduction of currency mismatches comes at the cost of additional maturity mismatches (Jeanneau and Tovar, 2006). For international 
investors, the attractiveness of these instruments depends on expectations of exchange rate appreciation, and their demand may thus be subject to strong procyclical swings. The advantages in terms of reduced currency mismatches for developing country issuers may thus not be accompanied by reduced volatility of external capital flows. This may lead, in turn, to a stronger link between exchange rate expectations and domestic interest rates. Minimum holding periods for the associated funds or exit taxes may thus be useful to get the full benefits from diversifying the currency risks but may reduce their attractiveness for international investors and the liquidity of these instruments.

FIGURE 2

\section{DOMESTIC BONDS ISSUED BY DEVELOPING COUNTRIES}

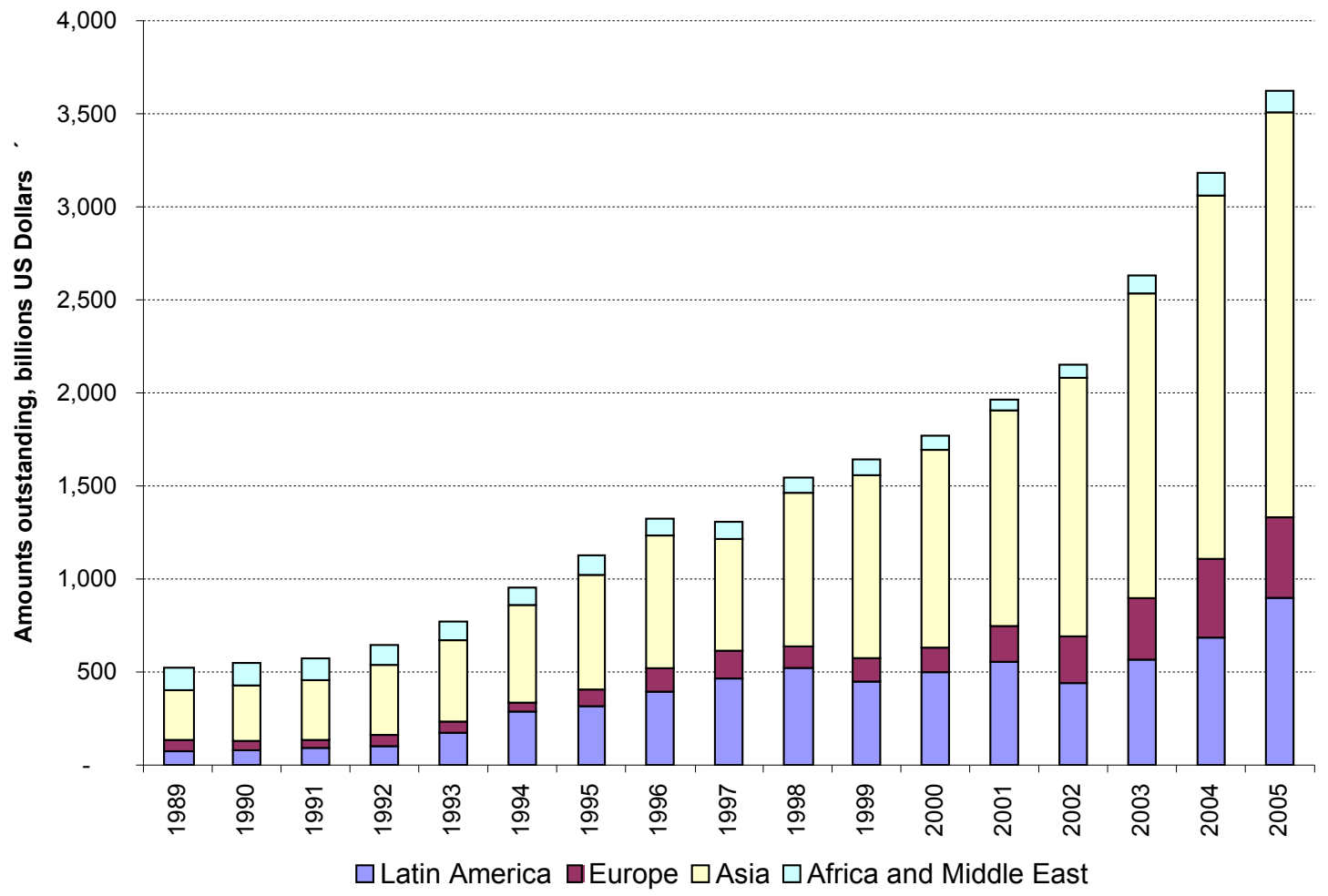

Source: Bank for International Settlements, ttp://www.bis.org/statistics/secstats.htm

Innovative proposals have been advanced to make local currency investments more attractive on a stable basis by international investors. Dodd and Spiegel (2005) have 
suggested raising capital in international markets by forming diversified portfolios of emerging market local currency debt issued by sovereign Governments. These portfolios would -by using risk management techniques of diversification- generate a return-to-risk that competed favorably with other major capital market security indices. A portfolio of emerging market local currency debt can raise rates of return relative to risk that compete with those of major US and European securities indices in international capital markets.

A similar effect could be achieved by multilateral development banks raising funds in the local markets of developing countries. The World Bank and the regional development banks could also design pilot projects of diversified bond issues that would provide information on returns, risk, and prices that could encourage private agents to emulate. The second Asian Bond Fund (ABF2) launched in December 2004 by the eleven EMEAP (Executives' Meeting of East Asia-Pacific Central Banks) is a pilot project of this type. All central banks invested in bonds denominated in domestic currencies of the eight EMEAP emerging economies. ${ }^{2}$

\section{Countercyclical guarantee facilities}

It is widely accepted that international financial markets overestimate risk in difficult times and underestimate it in good times. Private lenders' resulting boom-bust patterns are often more determined by changing global risk appetite and/or contagion rather than by country fundamentals. This provides a strong case for public institutions to play an explicit countercyclical role to help compensate for the inherent tendency of private flows to be procyclical. This is widely recognized in lending by IMF but applies equally to multilateral development banks (MDBs) and export credit agencies (ECAs). A particular case is guarantees for long-term trade credit for infrastructure investment. Indeed, private investment in infrastructure that had grown significantly during the early and mid-1990s, fell sharply in the wake of the numerous crises (Griffith-Jones and Fuzzo de Lima, 2006).

There could be two paths for increasing the countercyclical role of international financial institutions in this area. One would be for MDBs to provide more

\footnotetext{
${ }^{2}$ China, Hong Kong SAR, Indonesia, the Republic of Korea, the Philippines, Malaysia, Singapore and Thailand.
} 
countercyclical lending than already occurs (e.g., in infrastructure). Another path, which could provide more leverage of the public resources they manage, would be for MDBs and ECAs to be more active in issuing guarantees to private sector lenders with an explicit countercyclical element in the associated risk evaluations. This requires MDBs and ECAs to assess risk for issuing guarantees with a longer term perspective than typically done by commercial banks; when banks or other lenders lowered their exposure to a country, MDBs or ECAs would increase their level of guarantees if they considered that the country's long-term fundamentals were basically sound. When market risk evaluations improve and the willingness to lend increased, MDBs or ECAs could decrease their exposure.

To the extent that MDBs and ECAs increasingly use models to assess risks, taking a longer-term view would require the use of models with a longer-term perspective than those used by private lenders. These models would be presumably better at "seeing through the cycle", using more measures of risk focused on long-term factors.

It is important that guarantees should be tailor-made to correct market imperfections and avoid moral hazard. Otherwise, they might undermine the initiatives to enhance private capital flows to developing countries. First, they must maintain the private investors' incentives to choose only good projects - to avoid adverse selectionand run them efficiently. Second, guarantees can impose excessive costs on taxpayers or consumers and expose them to too much risk. To overcome this, it is crucial that contingent liabilities of guarantees be carefully monitored and their risks assessed. Furthermore, in the case of infrastructure projects, the risks to be guaranteed have to be carefully defined in such a way that private agents assume normal market risks (which can be subject, however, to some countercyclical evaluation), whereas non-market risks (such as regulatory risk or force majeure) should be subject to greater attention by authorities granting guarantees.

An alternative to mitigate risks is to push forward regional efforts to create guarantee agencies that enable risk sharing among countries that have common interests, including infrastructure development in neighbouring economies. This could enhance the creditworthiness of single country members and therefore of their government guarantees, especially in difficult times. 
This innovation could count with technical assistance of regional or sub-regional development banks. A sovereign guarantee pool could be developed as a contractual mechanism for risk sharing among governments that benefit from the same infrastructure project but have different credit ratings. The country with the higher rating could have an interest in having the project funded via this mechanism, due to positive externalities derived from the project. The lower rated country could compensate the guarantee coverage provided by its higher rated partner.

\section{The provision of countercyclical official liquidity}

\section{a. $\quad$ For capital-account-led crises}

At the country level, central banks have acted for many decades as lenders of last resort to prevent financial crises and their deepening when they occur. Equivalent international mechanisms are still at an embryonic stage, with the current IMF arrangements operating more under the principle of the "emergency financier", since there is no automaticity in the availability of financing during crises (Griffith-Jones and Ocampo, 2003). Enhanced provision of emergency financing at the international level in response to external shocks is essential to lowering unnecessary burdens of adjustment, and to avoid the spread of crises. Appropriate facilities should include a liquidity provision to cover large capital flow reversals and volatility in real export earnings.

In recent decades, capital-account liberalization and large capital-account volatility greatly increased the need for official liquidity to deal with large reversals in capital flows. There is increasing consensus that many of the recent crises in emerging markets have been triggered by self-fulfilling liquidity runs (see, for instance, Hausmann and Velasco, 2004; see also the case studies in this project). Indeed, capital outflows could be provoked by many factors not related to countries' policies.

The enhanced provision of emergency financing in the face of capital-account crises is thus important not only to manage crises when they occur, but to prevent such crises and to avert contagion (Cordella and Yeyati, 2005; Griffith-Jones and Ocampo, 2003). 
To address this obvious need, IMF has made efforts in recent years to improve its lending policy during capital-account crises. In 1997, the Supplemental Reserve Facility (SRF) was established. The evidence that even countries with good macroeconomic fundamentals might be subject to sudden stops of external financing also gave broad support to the idea that a precautionary financial arrangement, closer to the lender-of-lastresort functions of central banks, had to be added to existing IMF facilities. In 1999 the IMF introduced the Contingent Credit Line (CCL). The facility was never used and was discontinued in November 2003. Among the factors that may have contributed to the fact that countries failed to use it, observers have emphasized "entry" and "exit" problems (Buira, 2005). Contrary to what was desired, the potential use of the CCL was seen as an announcement of vulnerability that could harm confidence. Another problem was that the country had to go to the IMF Executive Board to secure a loan.

Since the expiration of the CCL, the IMF has been exploring other ways to achieve its basic objectives. As the IMF has recognized, the instant liquidity provided by a well-designed contingency line "would place a ceiling on rollover costs - thus avoiding debt crises triggered by unsustainable refinancing rates, much in the same way as central banks operate in their role of lenders of last resort" (IMF, 2005b). The Medium Term Strategy of the IMF (2005a) thus includes a provision for a continued dialogue on a mechanism of contingency financing. Based on proposals by the Managing Director of the IMF and approved by the International Monetary and Financial Committee in April 2006, a first proposal on a "Reserve Augmentation Line" (RAL) was put forward in August 2006. This line would be 300 per cent of quota for one year, the full amount being available from the outset. It would require prequalification, made at the country's request, that would allow the country to use the resources automatically when needed (IMF, 2006). Automaticity is, of course, essential for pre-empting liquidity runs. Some developing countries have expressed that the RAL is a step forward but that its design must be improved. The prequalification process and the amount of resources available under this line are likely to draw considerable debate.

The additional demand for IMF lending facilities that was evident during the succession of crises in the late 1990s implied that a significant strengthening of the resource base of IMF might be needed, and that the potential loss to the global economy 
of failing to act was much higher than the opportunity costs of a larger Fund size (Kelkar, Chaudhry and Vanduzer-Snow, 2005). Even though the IMF has recently sharply reduced its lending to emerging economies, in the absence of capital account crises, it is very important to maintain or expand its lending capacity to help prevent future crises.

\section{b. $\quad$ For compensating terms of trade shocks}

The provision of appropriate official liquidity to avoid costly and unnecessary adjustment to temporary terms of trade shocks is also important, particularly for lowincome countries, where these shocks have larger negative effects on growth and poverty (Collier and Pehn, 2001). Furthermore, low-income countries have limited room to build foreign exchange reserves as a buffer against such shocks.

The IMF has facilities to compensate for terms of trade shocks, but they are far too limited and in some cases have become more so in recent years. The major IMF facility designed in the 1960 s to compensate countries for terms of trade shocks, the Compensatory Financial Facility (CFF), has been used less and less, especially as its conditionality has been tightened. Indeed, since the modification of the CFF in 2000, when upper tranche conditionality was introduced as a condition for its use, the CFF has not been used at all in spite of relevant shocks.

As regards low-income countries with access to the high conditional Poverty Reduction and Growth Facility (PRGF), augmentation of such programmes has been the main vehicle used for countries hit by shocks. This has the advantage of concessionality. However, it is linked to a highly conditional Fund arrangement, inappropriate for shocks caused by external events. Secondly, as the IMF recognizes, PRGF augmentation was very small compared to the impact of the shock and granted to only half the PRGF countries experiencing shocks (IMF, 2005c).

In 2005 the IMF established a second concessional PRGF "window", called the Exogenous Shocks Facility (ESF), for countries without a PRGF programme that experience shocks (which also include natural disasters). It is also, however, a high conditionality arrangement and its scale is again limited. 
It seems, therefore, important that IMF facilities in these areas be modified following two criteria. First, far lower conditionality should be attached to lending for externally caused shocks, whether for middle- or low-income countries. Indeed, the original CFF and the Oil Facilities had such low conditionality and were amply as well as efficiently used. This recognized the principle that countries should not adjust policies (if these are reasonable) when faced with purely exogenous and temporary shocks. Second, the scale of existing facilities, including the concessional component in the case of lowincome countries, should be significantly expanded, to compensate for a far larger proportion of temporary shocks. This would reduce negative unnecessary effects on growth and poverty reduction.

A reason given for the small scale of PRGF augmentation and the ESF is the lack of concessional resources in the IMF. However, in a context of fairly rapid scaling up of aid flows, higher resources should be allocated to the IMF for financing the subsidy element of such compensatory lending.

\section{Macroeconomic cooperation among developing countries}

Contrary to the rich historical experience in the area of development financing, there is a dearth of experiences in the area of macroeconomic cooperation in the developing world. ${ }^{3}$ However, several initiatives have been launched in recent years often aiming to replicate European arrangements. European macroeconomic cooperation emphasized building strong institutions and subordinated capital mobility to other objectives of regional macroeconomic cooperation, particularly real exchange rate stability to facilitate regional trade integration (Wyplosz, 2006). In the developing world, although intraregional trade links are weaker (though growing rapidly in some regions, particularly in East Asia), two additional rationales are present: building defenses against global financial shocks, and avoiding distorting competition among export-oriented economies (Sakakibara, 2003).

More than monetary unions -which in the developing world have been neither abundant nor successful-, the European experience has encouraged looser forms of macroeconomic dialogue among developing countries. Different initiatives break up

\footnotetext{
${ }^{3}$ See United Nations (1999), Culpeper (2006), Mistry (1999) and Ocampo (2006).
} 
macroeconomic cooperation into its three basic components: macroeconomic policy dialogue and eventual policy consultation and surveillance; liquidity support during crises; and exchange rate coordination (Ocampo, 2006). The frequency of shocks faced by developing countries eliminate (or significantly postpone) the desirability of the third component -which was the major objective of European macroeconomic cooperation.

The first of these components of cooperation has been reflected in the adoption of Maastricht-type criteria in the context of several integration processes in sub-Saharan Africa and in Latin America and the Caribbean. However, unless these criteria leads to regular surveillance and consultation processes that help internalize effects of macroeconomic policies on regional partners, their credibility and rationale may be totally lost. In the developing world, it is also necessary to strike a balance between targets and policy flexibility, essential for economies subject to large shocks.

The experience of Latin America in this regard (Machinea and Rozenwurcel, 2006) indicates that, exchange of information and periodic technical meetings help build knowledge and mutual trust, the transition to more explicit coordination mechanisms is difficult. Furthermore, a major incentive for policy coordination that was important in Europe, the ability to "borrow credibility" from neighbors, has been absent.

The ASEAN Surveillance Process, adopted in 1998, is probably the most advanced of its kind. However, neither this mechanism nor the less structured ASEAN+3 (now integrated into the Chiang Mai Initiative) qualify as effective surveillance processes, due to the overemphasis on consensus and non-interference in the peer review process.

The second component of cooperation -liquidity support during crises-could provide an important incentive for macroeconomic coordination among developing countries but has been widely underutilized in the developing world. The experience of the Latin American Reserve Fund demonstrates that even a modest fund can make essential contributions to the balance-of-payments financing of developing countries (Titelman, 2006). Since 1978, this Fund provided such financing to member States, equivalent to $60 \%$ of that of IMF, benefiting in particular its smallest members. Its financing was clearly countercyclical, and its "preferred-creditor status" has been 
reflected in its healthy portfolio, even in the face of two major crises. Furthermore, Agosin (2001) estimated that, during recent decades, even a relatively modest fund, equivalent to $15 \%$ of Latin America's international reserves, could have provided financing to cope with capital outflows equivalent to the entire short-term debts of all countries, except Mexico.

The most ambitious project of this kind is the Chiang Mai Initiative, agreed upon in 2000 by ASEAN+3 (Park, 2006). The agreed mechanism is the negotiation of bilateral swap arrangements among the central banks of the member countries, which added up to US\$ 71.5 billion in February 2006. Aside from liquidity financing, the mechanism has provided an instrument of policy dialogue and a surveillance mechanism (which is deemed essential by net contributors, particularly Japan). The mechanism entitles countries to an automatic disbursement of up to $20 \%$ of the maximum amount of drawings, but beyond that a formal IMF programme is required. A modest step towards the multilateralization of bilateral swaps was taken in May 2005, when it was decided that the swap-activation process would be based on a collective decision-making process. The mechanism has not yet been utilized and, indeed, the buoyant conditions of the member countries in recent years may have slowed down the pace of action.

The recent decision to multilateralize the swap arrangement could lead to reserve pooling and even serve to back a common reserve currency. If a strong surveillance mechanism is put in place, financing could be detached from an IMF program. In addition, the policy dialogue could also eventually evolve into a more formal system of policy coordination. Also, if the membership of the Initiative is expanded to include other countries (particularly India), the system could eventually evolve into a fully fledged Asian monetary system (Rana, 2005). This is more likely if the issue of Asian countries' voice and participation in the IMF is not solved in an acceptable manner.

\section{Conclusions}

Volatility and contagion in international financial markets increased incidence of financial crises and growth volatility in the developing world, and reduced "policy space" to adopt countercyclical macroeconomic policies. Therefore, this paper argues that the major task of a development-friendly international financial architecture is to mitigate 
procyclical effects of financial markets and open "policy space" for countercyclical macroeconomic policies in the developing world.

To achieve these objectives, the paper explores a series of useful policy instruments: explicit introduction of countercyclical criteria in the design of prudential regulatory and supervisory frameworks; designing market mechanisms that better distribute the risk faced by developing countries throughout the business cycle (GDPindexed and local currency bonds); multilateral instruments that encourage more stable private flows, such as countercyclical guarantees; and better provision of countercyclical official liquidity to deal with external shocks. It also suggests that some forms of macroeconomic cooperation among developing countries can play a role, particularly regional macroeconomic consultation, and common reserve funds or swap arrangements.

\section{References}

Agosin, Manuel (2001), "Strengthening Regional Financial Cooperation," CEPAL Review 73 (April). Santiago, Chile: Economic Commission of Latin America and the Caribbean (ECLAC).

Bank for International Settlements (BIS) (2005), $75^{s t}$ Annual Report, June, Basel. (2001), $71^{\text {st }}$ Annual Report, June, Basel.

Bordo, Michael, Barry Eichengreen, Daniela Klingebiel and María Soledad MartínezPeria (2001), "Is the Crisis Problem Growing More Severe?", Economic Policy 32, April: 51-82.

Borensztein, Eduardo and Paolo Mauro (2004), "The Case for GDP-indexed Bonds." Economic Policy, April, pp. 165-216.

Buira, Ariel (2005), "Financial crises and international cooperation: Briefing note prepared for "the Orderly Resolution of Financial Crises: A G20-led Initiative"”, 29 and 30 January 2005, Mexico. Available from www.globalcentres.org.

Calvo, Guillermo and Ernesto Talvi (2004). "Sudden Stop, Financial Factors and Economic Collapse: A View from the Latin American Frontlines". Paper presented in the Universal Forum for Cultures, Barcelona, September.

, Leonardo Leiderman, and Carmen Reinhart (1993). "Capital Inflows and Real Exchange Rate Appreciation in Latin America: The Role of External Factors". IMF Staff Papers 40, March, pp. 108-151.

Collier, Paul, and Jan Dehn (2001), “Aid, shocks and growth”, Policy Research Working Paper, No. 2688, World Bank 
Cordella, Tito, and Eduardo Levy Yeyati (2005). A (New) Country insurance facility. IMF Working Paper, No. 05/23, January.

Culpeper, Roy (2006), "Reforming the Global Financial Architecture: The Potential of Regional Institutions", in José Antonio Ocampo (ed.), Regional Financial Cooperation, Washington, DC: Brookings Institution Press and ECLAC.

Dodd, Randall and Shari Spiegel (2005), "Up from Sin: A Portfolio Approach to Financial Salvation," in Ariel Buira (ed.), The IMF and the World Bank at Sixty, London: Anthem Press, pp. 85-115.

Easterly, William (2001), The Elusive Quest for Growth, Cambridge, Massachusetts: MIT Press.

, Roumeen Islam and Joseph E. Stiglitz (2001), "Shaken and Stirred: Explaining Growth Volatility", in Boris Pleskovic and Nicholas Stern (eds). Annual Bank Conference on Development Economics 2000, Washington, DC: World Bank, pp. 191-211.

Eichengreen, Barry (2004), "Global imbalances and the lessons of Bretton Woods", NBER Working Paper, No. 10497, May.

, Ricardo Hausman and Ugo Panizza (2003). "Currency Mismatches, Debt Intolerance and Original Sin: Why they are not the same and why they matter". NBER Working Paper 10036, October, National Bureau for Economic Research, Cambridge, MA.

Fanelli, José María (2006), "Macro Volatility and Financial Institutions", Background paper for the IDRC/CEDES Project on "International Financial Architecture, Macro Volatility and Institutions: The Developing Country Experience”, Buenos Aires, May.

Fernández de Lis, Santiago, Jorge Martínez and Jesús Saurina (2001), "Credit Growth, Problem Loans and Credit Risk Provisioning in Spain", BIS Papers, No. 1, pp. 310-30.

Ffrench-Davis, Ricardo (2001). Financial Crises in 'Successful' Emerging Economies. Washington DC: Brookings Institution Press and ECLAC.

Frenkel, Roberto (2005), "External Debt, Growth and Sustainability", in José Antonio Ocampo (ed.), Beyond Reforms: Structural Dynamics and Macroeconomic Vulnerability. Palo Alto: Stanford University Press and ECLAC, pp. 189-209.

Griffith-Jones, Stephany and Ana Teresa Fuzzo de Lima (2006) 'Mitigating the Risks of Investing in Developing Countries; Currency-Related Guarantee Instruments for Infrastructure', in Inge Kaul and Pedro Conceicao (eds) The New Public Finance: Responding to Global Challenges, New York: Oxford University Press 
and Krishnan Sharma (2006), "GDP-Indexed Bonds: Making It Happen”, DESA Working Paper, No. 21

and José Antonio Ocampo (2003), What Progress on International Financial Reform? Why so Limited? Stockholm: Expert Group on Development Issues, (EGDI).

, Miguel Angel Segoviano and Stephen Spratt (2003), "CPE and the Developing World", Submission to the Basel Committee on Banking Supervision, www.stephanygj.com

Group of 24 (2005), Communiqué, September 23.

Hausmann, Ricardo, and Ugo Panizza (2003), "On the Determinants of Original Sin: An Empirical Investigation", Journal of International Money and Finance 22, pp. 957-90.

and Andrés Velasco (2004), "The Causes of Financial Crises: Moral failure versus Market Failure", December. Available from http://ksghome.harvard.edu.

International Monetary Fund (IMF) (2006), "Consideration of a New Liquidity Instrument for Market Access Countries", Washington, DC August 3.

(2005a), The Managing Director's Report On The Fund's Medium-Term Strategy, Document Presented to the International Monetary and Financial Committee, Washington, DC, September 15.

(2005b), “Contingent Financing”, IMF Survey, April .

(2005c), "Evaluation of PRGF", Document presented to the Executive Board, July

(2004), "Assessing Sustainability", Document presented to the Executive Board, May 28.

(1998), World Economic Outlook, 1998 - Financial Crises: Characteristics and Indicators of Vulnerability, Washington, DC, May.

Jeanneau, Serge and Camilo E. Tovar (2006), "Domestic Bond Markets in Latin America: Achievements and Challenges", BIS Quarterly Review, June, pp. 51-64.

Kaminsky, Graciela L., Carmen M. Reinhart and Carlos A. Végh (2004), "When It Rains, It Tours: Pro-cyclical Capital Flows and Macroeconomic Policies", NBER Working Paper No. 10780, September.

Kelkar, Vijay L., Praveen K. Chaudhry and Marta Vanduzer-Snow (2005), "Time for change at the IMF", Finance \& Development, March.

José Luis Machinea and Guillermo Rozenwurcel (2005), "Macroeconomic Coordination in Latin America: Does it Have a Future?", in José Antonio Ocampo (ed.), 
Regional Financial Cooperation, Washington, DC: Brookings Institution Press and ECLAC.

Marfán, Manuel (2005), "Fiscal Policy, Efficacy and Private Deficits: A Macroeconomic Approach", in José Antonio Ocampo (ed.), Beyond Reforms: Structural Dynamics and Macroeconomic Vulnerability, Palo Alto: Stanford University Press and ECLAC, pp. 161-188.

Minsky, Hyman P. (1982), Can "It" Happen Again?: Essays on Instability and Finance. Armonk, NY: M.E. Sharpe.

Mistry, Percy S. (1999), "Coping with Financial Crises: Are Regional Arrangements the Missing Link?", International Monetary and Financial Issues for the 1990s, Vol.10. Geneva: United Nations Conference on Trade and Development (UNCTAD).

Ocampo, José Antonio (2006), "Regional Financial Cooperation: Experiences and Challenges", in José Antonio Ocampo (ed.), Regional Financial Cooperation, Washington, DC: Brookings Institution Press and ECLAC.

(2005), “A Broad View of Macroeconomic Stability”, DESA Working Paper, No. 1 , October.

(2003), "Capital Account and Counter-Cyclical Prudential Regulation in Developing Countries", in Ricardo Ffrench-Davis and Stephany Griffith-Jones (eds), From Capital Surges to Drought: Seeking Stability for Emerging Markets, London: Palgrave Macmillan, pp. 217-44.

, Jan Kregel and Stephany Griffith-Jones (2006), International Finance and Development,

and Juan Martin (2003), Globalization and Development, Palo Alto: Stanford University Press and ECLAC.

Park, Yung Chul (2006), "Regional Financial Integration in East Asia: Challenges and Prospects", in José Antonio Ocampo (ed.), Regional Financial Cooperation, Washington, DC: Brookings Institution Press and ECLAC.

Persaud, Avinash (2000), Sending the Herd off the Cliff Edge: The Disturbing Interaction between Herding and Market-sensitive Risk Management Practices, London: State Street Bank.

Prasad, Eswar S., Kenneth Rogoff, Shang-Jin Wei and M. Ayhan Kose (2003), "Effects of Financial Globalization on Developing Countries: Some Empirical Evidence", IMF Occasional Paper 220, Washington DC.

Rana, Pradumna B. (2005), "Economic Integration in East Asia: Trends, Prospects, and a Possible Roadmap," Paper presented at the Third High-Level Conference on 
Building a New Asia: Towards an Asian Economic Community, Taiyuan, China, September 15-16.

Rodrik, Dani, and Andrés Velasco (2000), "Short-Term Capital Flows", in Proceedings of the Annual World Bank Conference on Development Economics 1999, Washington DC: World Bank, pp. 59-90.

Sakakibara, Eisuke (2003), "Asian Cooperation and the End of Pax Americana," in Jan Joost Teunissen and Mark Teunissenm (eds.), Financial Stability and Growth in Emerging Economies: The Role of the Financial Sector, The Hague: FONDAD, pp. 227-240.

Souza, Francisco Eduardo Pires de, Getúlio Borges da Silveira and Fernando J. Cardim de Carvalho (2006), Country Study of Brazil for the IDRC/CEDES Project on "International Financial Architecture, Macro Volatility and Institutions: The Developing Country Experience".

Stiglitz, Joseph E. (2003), "Whither Reform? Toward a New Agenda for Latin America". CEPAL Review, 80, pp. 7-38.

Titelman, Daniel (2006), "Subregional Financial Cooperation: The Experiences of Latin America and the Caribbean", in José Antonio Ocampo (ed.), Regional Financial Cooperation, Washington, DC: Brookings Institution Press and ECLAC.

United Nations, Executive Committee on Economic and Social Affairs (1999), Towards a New International Financial Architecture. Santiago: ECLAC.

United Nations (2006), World Economic and Social Survey 2006: Diverging Growth and Development, New York.

White, William (2006), "Procyclicality in the financial system; do we need a new macrofinancial stabilization framework?," BIS Working Paper 193, June

Wyplosz, Charles (2006), "Regional Exchange Rate Arrangements: The European Experience", in in José Antonio Ocampo (ed.), Regional Financial Cooperation, Washington, DC: Brookings Institution Press and ECLAC. 